\title{
A construção dos fundamentos conceituais da Economia Solidária
}

\author{
Dyego de Oliveira Arruda' \\ Milton Augusto Pasquotto Mariani ${ }^{2}$
}

\section{Resumo}

O presente trabalho tem como objetivo geral lançar luz acerca dos fundamentos basilares da economia solidária, situando-a no que tange aos aspectos históricos, sociológicos e até mesmo econômicos que lhe são pertinentes. Entende-se que a economia solidária - como quadro referencial das ciências sociais - erigiu-se numa perspectiva de adaptação/negação dos desígnios acumulativos e excludentes do modo de produção capitalista, numa tentativa de humanização deste sistema. Logo, todo o quadro analítico da economia solidária foi construído neste trabalho a partir desta perspectiva de adaptação/negação dos fundamentos basilares do sistema capitalista. Trata-se, portanto, de um artigo decorrente de uma pesquisa essencialmente qualitativa, de caráter descritivo e exploratório - sobretudo por conta da contemporaneidade do tema. Entende-se que, mediante ao levantamento das informações, urgem pesquisas acerca das próprias práticas de economia solidária contemporâneas, situando-as no seio das políticas públicas, bem como no âmbito da evolução da economia solidária como movimento organizado.

Palavras-chave: Economia solidária. Capitalismo. Sociologia

\section{Introdução}

O termo economia solidária, tomado de forma estanque e desgarrado do contexto histórico/sociológico que lhe dá corpo, constitui-se em objeto

1 Doutorando em Administração de Organizações pela Universidade de São Paulo (USP) - Faculdade de Economia, Administração e Contabilidade de Ribeirão Preto (FEA-RP/USP), Ribeirão Preto, São Paulo, Brasil. É autor de artigos publicados nas revistas: Estudios y Perspectivas en Turismo, 2013; Revista Brasileira de Ecoturismo, 2013; Revista Acadêmica Observatório de Inovação do Turismo, 2012, entre outras. E-mail: dyego.arruda@gmail.com.

2 Doutor em Geografia (Geografia Humana) pela Universidade de São Paulo (200I) e docente da Universidade Federal de Mato Grosso do Sul (UFMS). Campo Grande. Mato Grosso do Sul, Brasil, credenciado nos programas de mestrado em Administração e Estudos Fronteiriços. É autor de artigos publicados nas revistas: Turismo: Visão e Ação (Online), 2013; Revista Brasileira de Ecoturismo, 2013; Estudios y Perspectivas en Turismo (En Linea), 2013, entre outras. E-mail: miltmari@terra.com.br. 
analítico de recorrente imprecisāo teórica à medida que encarna duas ambiguidades básicas: uma, por supor 'espécimes de economia' diferenciados e autônomos; a outra por tipificar a economia por preceitos de solidariedade, incongruentes aos fundamentos hedonistas e autonomistas característicos ao sistema capitalista (que constitui a forma de organizaçáo socioprodutiva dominante) desde a publicação de A Riqueza das Naçóes, por Adam Smith, em 1776.

De todo modo, à revelia das iniciativas compartimentadas de definição do conceito de economia solidária, e tomando-se como base o contexto de precarizaçáo do trabalho assalariado e a ampliaçáo dos níveis de desemprego sob os quais supostamente repousa a origem da economia solidária - ao menos do ponto de vista teórico, nota-se que seu aspecto diferenciador reside numa questão de lógica, que toma o trabalho assalariado e as forças socioprodutivas como meios para o alcance do bem-estar humano, e náo como fins inerentes à acumulaçáo de lucro e concentraçáo individual do capital, conforme preconizado pela economia capitalista.

Sendo assim, dada a preponderância do bem-estar dos indivíduos como elemento intrínseco às práticas características da economia solidária, nota-se que este movimento majoritariamente insere-se nas discussóes acerca dos métodos de promoçáo do desenvolvimento socioeconômico - onde se incorporam (só para citar alguns exemplos) análises acerca de economias de escala e escopo; vantagens competitivas de aglomeração; cadeias produtivas; distribuição efetiva de renda etc.

A economia solidária, uma vez inserida no escopo dos movimentos sociais, apresenta uma miríade de nuances, dentre as quais: a ênfase no emprego e na geraçáo de renda para os indivíduos espoliados do mercado de trabalho formal - proposta muito comum no Brasil, sobretudo a partir dos trabalhos de Singer $(2002,2006)$; o destaque para a construçáo de uma nova sociedade e de novas sociabilidades a partir do trabalho cooperado e/ou associado, conforme se preconiza na Europa e no México; além da própria filosofia da dádiva e do bem viver, muito comum na Áustria. No âmbito deste trabalho, adotam-se as ponderaçóes de Singer (2002, 2006).

Porém, antes de pensar aspectos específicos no que toca às consequências das práticas de uma economia solidária, percebe-se - muito por conta da contemporaneidade do tema - a necessidade de uma investigaçáo do estado 
da arte inerente à temática, bem como uma reflexão sobre as características estruturais/conjunturais das práticas de economia solidária contemporâneas. Portanto, urge a necessidade do estabelecimento de uma verdadeira revisáo da economia solidária - situando-a no que concerne aos fundamentos históricos, sociológicos e até mesmo econômicos, que lhe são pertinentes.

A abordagem preliminar utilizada neste trabalho - anterior ao estabelecimento de toda a perspectiva teórica do assunto em tela - toma a economia solidária como o conjunto de açóes socioeconômicas oriundo de um contexto de desocupação, baixa qualidade dos empregos e desproteçáo social dos trabalhadores assalariados - perfazendo, pois, uma alternativa de geraçáo de renda econômica. Tais açóes embasam-se em uma lógica de desalienação do trabalho e bem-estar dos trabalhadores, organizados sob a forma de cooperativas ou associaçōes socioprodutivas, arraigadas dos seguintes princípios basilares: a autogestão administrativa; a solidariedade organizativa; além da igualdade no processo de tomada de decisóes e nas iniciativas de repartição das receitas das organizaçóes.

Alguns autores, sobretudo quando se remete aos partidários das análises dos movimentos sociais - tais como Novaes (2010), Benini e Benini (2010), Batista e Novaes (2011), entre outros - interpretam a economia solidária como um novo modo de produção, passível de uma abordagem revolucionária de superaçáo dos desígnios acumulativos/excludentes inerentes ao sistema capitalista. Outros teóricos, mais alinhados à discussão instrumental da economia solidária - dentre os quais estáo Barbosa (2007), Coriolano (2008), entre outros - a tipificam como um mecanismo de política pública; ou como a síntese de açóes que visam à inserção social ativa dos indivíduos/trabalhadores no capitalismo, numa clara demonstração de 'humanizaçáo' do sistema capitalista e, por conseguinte, da economia.

Por ora, pode-se perceber que o levantamento do estado da arte inerente à economia solidária náo se resume em um expediente simples, sobretudo por conta da constataçáo das múltiplas abordagens sob as quais a temática é interpretada. Em parte, tal dinâmica é explicada pela contemporaneidade do marco teórico sobre a economia solidária, que surgiu na última década do século XX e ainda é passível de aprimoramento conceitual. De outra parte, tal divergência de definiçôes e abordagens é natural nas práxis normativas da ciência (sobretudo da ciência social) que tem seus conceitos (re)formulados conforme os processos históricos e socioeconômicos sob os quais é interpretado. 
Ademais, além das problemáticas acima pontuadas, nota-se que o termo economia solidária nâo raro é refletido e conceituado de forma polissêmica (LECHAT, 2002; FRANÇA FILHO, 2002). Notam-se, na literatura corrente, os termos economia social (GUÉSLIN, 1998), economia popular (NASCIMENTO, 2007), ou até economia do terceiro setor (FRANÇA FILHO, 2002), como sendo sinônimos do termo economia solidária. Porém, a despeito disso, o presente trabalho se furta à discussão dessa questáo polissêmica, utilizando o termo corrente 'economia solidária', tomando-a como um movimento gestado no contexto de desemprego e desproteçáo social proposto por Singer $(2002,2003,2006)$.

Portanto, diante das supracitadas provocaçóes e constataçóes de pesquisa, o presente trabalho tem como escopo basilar lançar luz nos fundamentos característicos da economia solidária como campo de análise das ciências sociais, sobretudo no que tange às dinâmicas históricas, sociológicas e econômicas inerentes à construçáo deste quadro analítico.

Vale ponderar que a economia solidária, no âmbito deste trabalho, é entendida como um verdadeiro movimento, calcado na organizaçáo dos indivíduos de forma autônoma, em contraposiçáo à premissa de alienaçáo da máo de obra e exploraçáo da força de trabalho assalariada. O supracitado movimento, paulatinamente, ganha forças, sobretudo a partir da criaçáo de instituiçóes que visam a sua difusáo (tais como a Secretaria Nacional de Economia Solidária do Ministério do Trabalho e Emprego - SENAES/MTE). Ademais, nâo se pode desprezar a incorporação dos princípios fundamentais da economia solidária no seio dos grupos sociais - tais como grupos desempregados - o que, conjuntamente, concorre para a solidificação do referido movimento de economia solidária.

Em suma, o presente trabalho está estruturado em quatro partes - além desta introduçáo. Na primeira parte, descrevem-se alguns breves traços de fundo metodológico que nortearam a realização do presente trabalho. $\mathrm{Na}$ segunda parte, expóem-se os fundamentos de caráter histórico e sociológico acerca da construção dos fundamentos basilares da economia solidária. $\mathrm{Na}$ terceira parte, apresentam-se os 'fundamentos econômicos' da economia solidária. Por fim, na quarta e última parte, elucidam-se as consideraçóes finais decorrentes da presente pesquisa, elencando algumas questóes provocativas 
em termos da construção de uma agenda para possíveis pesquisas futuras acerca da temática da economia solidária.

\section{Procedimentos metodológicos}

Antes de expor as características básicas do quadro referencial acerca da economia solidária, faz-se necessário realçar alguns traços metodológicos que nortearam a realizaçáo da presente pesquisa. Logo, vale ponderar preliminarmente que a pesquisa apresenta caráter essencialmente qualitativo, empregando diferentes concepçóes e paradigmas das ciências sociais para a interpretação holística do fenômeno estudado - tais como os fundamentos da sociologia, história e economia política (CRESWELL, 2010).

Ademais, deve-se destacar o caráter descritivo exploratório do presente trabalho, sobretudo por conta da contemporaneidade do tema, bem como em virtude da escassez de estudos e pesquisas científicas que tratem dos fundamentos basilares da economia solidária e - particularmente - das dinâmicas contemporâneas deste movimento.

Parte-se do pressuposto - conforme já se fez menção na introdução deste trabalho - que a economia solidária pode ser interpretada como uma reaçáo às dinâmicas do modo de produção capitalista, numa verdadeira inversão da lógica analítica deste sistema. Portanto, os fundamentos conceituais característicos da economia solidária sáo construídos a partir de uma negação/adaptação dos próprios fundamentos do sistema capitalista (MARX, 1975). Entende-se, notadamente, que esta opção metodológica dá maior consistência à elaboraçáo de todo o quadro analítico deste trabalho.

\section{Capitalismo industrial e desigualdades sociais: em tela, a construção dos fundamentos históricos/sociológicos da economia solidária ${ }^{3}$}

Pensar o conceito de economia solidária sob uma perspectiva histórico-sociológica remonta ao período imediatamente posterior ao surgimento e à

3 Ao longo deste tópico, as questões históricas e sociológicas (e, em algumas passagens, até mesmo algumas questões econômicas) inerentes aos fundamentos e origens históricas da economia solidária aparecerão imbricadas. Entende-se que tal expediente contribui para uma maior leveza ao texto. 
consolidação do capitalismo industrial, em fins do século XVIII e princípio do século XIX. Nesta época, a economia solidária - como uma forma de pensar regida por uma lógica distinta dos princípios inerentes à economia capitalista - mostra-se como "[...] uma reação ao espantoso empobrecimento dos artesãos provocado pela difusão das máquinas e da organização fabril da produçáo" (SINGER, 2002, p. 24).

O sistema capitalista - calcado nos seus princípios de individualidade, autonomia, liberdade e fundamentando-se na lógica de acumulaçáo privada de lucro - foi capaz de proporcionar à humanidade um intenso progresso tecnológico, modificando e adaptando a natureza sob fins produtivistas, embasando-se para tanto na pretensa bandeira de ampliaçáo dos lucros e, por conseguinte, de aumento da utilidade social das forças produtivas (NUNES, 2009; ARROYO; SCHUCH, 2006). Porém, esta mesma tônica característica do capitalismo, por resultar na desigualdade social e na competição entre a força de trabalho, insuflou "uma situaçáo de ameaças constantes de barbárie e caos social (miséria e violência)” (BENINI, 2008, p. 19).

Ao estabelecer uma caricatura das mazelas sociais inerentes ao período que marca a consolidaçấo do capitalismo industrial, os registros históricos dão conta de que a exploraçáo do trabalho nos ambientes fabris náo tinha limites, de tal modo que muitos trabalhadores morriam por pura e simples exaustáo física, o que ameaçava a própria reproduçáo biológica do proletariado. "As crianças começavam a trabalhar táo logo podiam ficar de pé, e as jornadas de trabalho eram táo longas que o debilitamento físico dos trabalhadores e sua elevada morbidade e mortalidade impediam que a produtividade do trabalho pudesse se elevar" (SINGER, 2002, p. 24).

Sendo assim, diante deste quadro social marcadamente instável, surgem as primeiras iniciativas de contestaçáo da racionalidade instrumental ${ }^{4}$ do

4 A racionalidade instrumental trata-se dos agenciamentos das forças produtivas (em que se insere o trabalho) como meios para a obtenção de lucros - que é o fim último do ciclo produtivo inerente ao sistema capitalista (CATTANI, 2003).

Ao longo do trabalho, em várias passagens remeter-se-á às politicas públicas em economia solidária como sendo passiveis de uma abordagem por intermédio da racionalidade instrumental - nominando-as, nesse viés, como "políticas públicas de caráter instrumental". Não se pretende, com isto, descaracterizar a lógica imanente à economia solidária elou confundir o leitor. Espera-se, sim, tomar a economia solidária como meio para o alcance do fim último das políticas públicas - que se refere à ingerência Estatal nas questões socioeconômicas. Para mais detalhes, ver Barbosa (2007). 
sistema capitalista, sobretudo por parte de intelectuais mais esclarecidos, não raro ligados à atividade industrial. Dentre tais pensadores, pode-se destacar como os mais proeminentes os franceses Saint Simon e Charles Fourrier; e o inglês Robert Owen, que, por intermédio dos falanstérios (Fourrier) e das aldeias cooperativas (Owen) encamparam iniciativas que ficaram designadas como constituintes de um 'socialismo utópico'.

Motta (1987) entende que tais propostas ditas utópicas consideravam a existência (e, consequentemente, a possibilidade de materializaçáo) de um mundo ideal, regido por princípios de igualdade e de justiça para todos. Porém, a despeito disto, os adeptos do socialismo utópico náo propunham os métodos para a organizaçáo social em torno de tais aspiraçóes. "Essas experiências [inerentes ao socialismo utópico] eram baseadas na influência marcante de seus idealizadores - geralmente intelectuais progressistas - e não, de modo geral, na organização autônoma dos próprios trabalhadores" (NUNES, 2009, p. 41).

Uma das iniciativas pioneiras de negaçáo das mazelas inerentes ao sistema capitalista originária, em parte, no bojo dos próprios movimentos de trabalhadores foi a Comuna de Paris, em 1871. Considerada a primeira revoluçáo comunista da história, tal movimento centrava-se em um governo regido autonomamente pelos trabalhadores, pleiteando reformas que só seriam efetivamente programadas dezenas de décadas mais tarde, como um teto de oito horas para a jornada de trabalho ou a igualdade de gêneros (GUILLERM; BOURDET, 1976).

Vale ponderar que, a despeito do aspecto motivador das organizaçóes socioeconômicas calcadas em princípios de igualdade e solidariedade, nota-se que - do ponto de vista meramente microeconômico - tais empreendimentos apresentavam vantagens, sobretudo no que se refere ao viés organizacional, já que os trabalhadores - uma vez motivados e detentores do mínimo de direitos - acabavam produzindo mais e melhor.

Agora, no que se refere à perspectiva que vai além do aspecto microeconômico e organizacional - considerando-se, pois, o ambiente macroeconômico e social onde as iniciativas socioeconômicas de caráter igualitário encontravam-se inseridas - fica patente a presença de um viés transformador inerente à atuação política dessas organizaçóes. Neste ínterim, o movimento socialista, desde as primeiras iniciativas utópicas de Owen e Fourier, propóe a 
construção de uma 'nova sociedade' fundamentada nos preceitos de igualdade e solidariedade - em contraposição aos fundamentos do modo de produçáo dominante, ou seja, do modo de produçáo capitalista.

Portanto, nota-se que os princípios fundamentais da economia solidária têm suas origens históricas enraizadas na gênese do próprio movimento socialista, ou seja, no processo de contraposiçáo aos fundamentos do modo de produçáo capitalista.

Logo, com base em Singer (2002), Pinto (2006), França Filho et al. (2006), e até mesmo rememorando os aspectos metodológicos expostos por Polanyi (2000) e Block e Polanyi (2003) e as sugestóes da práxis socialista evidente em Mészáros (2005), entende-se que, no intento de se analisar a economia solidária sob uma perspectiva histórica/sociológica, pode-se partir da (des)construçáo dos fundamentos do sistema capitalista - interpretando-se, naturalmente, a lógica da economia solidária como sendo historicamente originária pari passu a tais fundamentos, numa perspectiva de negaçáo/adaptaçáo dos princípios capitalistas. Sendo assim, resta (re)construir os movimentos dos princípios de competiçâo, desigualdade e heterogestão que notadamente constituem a base da lógica capitalista - que são contrapostos pelos princípios de solidariedade, igualdade e autogestão, intrínsecos à economia solidária.

Isto náo quer dizer, porém, que a economia solidária seja necessariamente interpretada sob um viés estritamente socialista e/ou dos movimentos sociais - esta é apenas uma dentre outras interpretaçóes possíveis. Por ora, apenas pretende-se descrever as origens históricas, sociológicas e econômicas dos fundamentos da economia solidária - o que necessariamente perpassa pela literatura de caráter socialista.

\section{I Competição: em debate, a gênese do comportamento imanente aos mercados capitalistas}

Analisar o princípio de competiçáo inerente ao sistema capitalista remonta às origens do conceito de liberalismo, bem como à própria gênese da economia política. Adam Smith (considerado um dos pais da ciência econômica moderna), ao negar as estruturas sociais hierarquizadas do Antigo Regime, propóe, já em 1776, a gênese de uma nova ordem econômica centrada na lógica do mercado e nas tônicas do liberalismo como sistema político-econômico 
dominante, em que a sociedade seria naturalmente direcionada rumo ao progresso e à igualdade por forças intrínsecas a um espécime de 'mão invisível' atuante na alocaçáo dos recursos da economia (SMITH, 1983). ${ }^{5}$

Nesta dinâmica, a competição - como princípio imanente ao comportamento dos mercados - constitui uma das bases do sistema capitalista em fase de consolidaçáo. Sendo assim, os indivíduos são portadores de autonomia para, uma vez municiados dos ideais de 'liberdade, igualdade e fraternidade', lançar-se no mercado, que por sua vez é dotado de uma virtude relegada à "inocência e à doçura do comércio e do enriquecimento via acumulação de lucros" (LAVILLE, 2006, p. 28).

A Revolução Francesa de 1789 exerce papel preponderante para a solidificação dos princípios intrínsecos aos mercados em padráo de competição. Ao contrastar as antigas estruturas hierarquizadas e autárquicas com a proposta de um 'governo do povo e para o povo', induz, involuntariamente, a tomada de poder por parte da burguesia esclarecida da época, que passa a ditar os rumos socioeconômicos e políticos pela coerçáo inerente à posse do capital (em contraponto à grande maioria da sociedade, espoliada até mesmo do mínimo que lhes garantissem a subsistência, conforme os registros de entáo) ${ }^{6}$. Assiste-se, portanto, às dinâmicas em que "uma nova forma de poder estava se constituindo: o poder do dinheiro; do capital" (NUNES, 2009, p. 40).

Ainda recorrendo a Laville (2006, p. 28) nota-se que, sob a batuta da competiçáo na economia capitalista,

[...] As relações mercantis parecem suscetiveis de refrear a violência inerente às relações humanas e o comportamento ditado pelo interesse econômico é dotado de potencial pacificador num processo que terminará esvaziando a noção de interesse de qualquer conotação que não seja econômica.

Nesse sentido, no decurso do século XIX (que marca a efetiva consolidaçáo da ciência econômica preconizada por Smith) a sociedade, sob regime de

5 Para mais detalhes sobre as essências teóricas de Adam Smith acerca do pensamento econômico, ver Carcanholo (1991).

6 Para mais detalhes de tais condições sociais, pode-se recorrer à Polanyi (2000), especialmente na segunda parte da obra, onde o autor em tela descreve as especificidades socais, bem como as características políticas da época anterior à Revolução Industrial na Europa. 
democracia - ao menos do ponto de vista normativo - relega a sua regulação ao mercado calcado em intensa competição, tutelada pelo incontestável princípio da máo invisível, que produz justiça num processo de transformaçáo dos vícios particulares em benefícios coletivos.

Sendo assim, nota-se um decurso de transformaçáo social, em que os indivíduos lançavam-se em atividades lucrativas e passíveis de acumulação de riquezas, num regime de mercado em competiçáo. Do ponto de vista moral, notam-se forças que impelem os sujeitos a tais comportamentos, como as filosofias calvinistas e weberianas, que postulavam a favor da ética protestante como elemento que outorgaria o individualismo e a autonomia de cada um em buscar a maximizaçáo da utilidade de seu trabalho, sob um ambiente de mercado em competiçấo (GOMES, 2003).

A ética protestante age no desenvolvimento do capitalismo, de duas maneiras convergentes e extremamente eficazes: sua moral do trabalho e do ativismo prático acumula a produção e força o enriquecimento; seu ascetismo, porém, oposto a todas as formas de luxo e de prazeres inúteis, freia o consumo de riquezas adquiridas e conduz ao acúmulo de capital. (BIÉLER, 1990, p. 637, grifo nosso).

Portanto, estariam definidas e consolidadas as tônicas sob as quais uma nova ordem socioeconômica - calcada no capital e na competiçáo - erigia-se. Não obstante, a história mostra que esta mesma ordem do capital náo foi capaz de propiciar a paz e o progresso sociais que tanto prometera. Muito pelo contrário, "sua difusão fez nascer uma questão social cuja acuidade resulta da extensáo imprevista da pobreza” (LAVILLE, 2006, p. 28).

"No coraçáo da Revoluçáo Industrial do século XVIII ocorreu um progresso miraculoso nos instrumentos de produção, o qual se fez acompanhar de uma catastrófica desarticulaçáo nas vidas das pessoas comuns" (POLANYI, 2000, p. 51). Sendo assim, algumas medidas - como o cercamento de terras na Inglaterra ${ }^{7}$, por exemplo - erigidas sob a pretensa ideia de ampliaçáo das vantagens competitivas de uma indústria nascente, resultou na pauperizaçáo e no despovoamento de grandes contingentes populacionais, que passaram a

7 O cercamento de terras (enclousured of land) na Inglaterra do século XVIII e XIX tipificou-se como uma medida (em parte chancelada pelo Estado) em prol da concentração de terras e ampliação produtiva no campo, com vistas à consecução de produtos subsidiários à atividade industrial. Para mais informações, ver Camargo Neto (2005). 
migrar para as cidades em busca do mínimo que lhes garantisse subsistir (não raro sendo-lhes negados até mesmo estes recursos básicos).

Nesse ínterim, "[...] para vários pensadores e operários confrontados à miséria, a amplitude intolerável das desigualdades obriga um outro mecanismo de coordenaçáo: a solidariedade" (LAVILLE, 2008, p. 22, grifo nosso).

\section{i) A solidariedade em contraposição à competição}

Diante da iminência da solidariedade como contraponto à competiçáo excludente, resta a idealização de um arranjo socioeconômico em que predominasse tal princípio como forma de consecuçáo do bem-estar social. "A solidariedade na economia só pode se realizar se ela for organizada igualitariamente pelos que se associam para produzir, consumir, comerciar ou poupar; a chave dessa proposta é a associação entre iguais em vez do contrato entre desiguais" (SINGER, 2002, p. 9, grifo do autor).

No entanto, muito embora o conceito de solidariedade pareça encerrar princípios e lógicas simples, restam algumas ponderaçóes, sobretudo acerca de sua gênese. Do ponto de vista sociológico, a solidariedade, interpretada como o conjunto de "[...] relaçóes nas quais o sentimento de pertencimento envolve, precede e motiva as interaçóes operadas pelos sujeitos", pode ser herdada dos grupos sociais nos quais os indivíduos se inserem (como as solidariedades inerentes a agrupamentos étnicos os mais variados), ou pode ser construida, seja por intermédio de forças que estabeleçam algum tipo de coerçáo sobre os grupos ou por meio da espontaneidade inerente às organizaçóes sociais (LAVILLE, 2006, p. 23).

A solidariedade herdada remete, notadamente, às relaçóes horizontais inerentes às comunidades primitivas, em que o senso de pertencimento comunitário era passado às geraçóes de descendentes, de forma natural. No entanto, com o passar dos tempos e com a complexidade das organizaçóes socioeconômicas modernas, nota-se que a solidariedade passa a resultar numa construçáo sob fins diversos, dentre os quais: controle social; contraponto à condiçáo de pauperismo e precarização social de muitos indivíduos; distinção social de alguns agrupamentos etc.

Dada esta complexidade contemporânea e, assim, procedendo a uma maior qualificação da solidariedade construída, nota-se a presença de novas 
conceituaçôes. Nesse ínterim, a solidariedade pode resumir-se como uma concepçáo filantrópica, às vezes concebida como uma 'questão de urgência' para aliviar determinados tipos de tensáo social, náo raro sob os auspícios do Estado, ou pode ser definida como uma construção democrática resultante de extrapolaçóes das necessidades coletivas, numa espécie de 'espaço público de interlocução' - não raro, com a função catalisadora do Estado. Utilizando-se, pois, da terminologia sacramentada por Laville (2009), no primeiro caso diz-se tratar de um tipo de solidariedade filantrópica; e no segundo caso tem-se uma solidariedade democrática.

A fim de clarear a distinção conceitual apresentada, o quadro a seguir elucida uma espécie de organograma acerca das definiçóes levantadas quanto ao conceito de solidariedade:

\section{Quadro I: Terminologias conceituais da solidariedade}

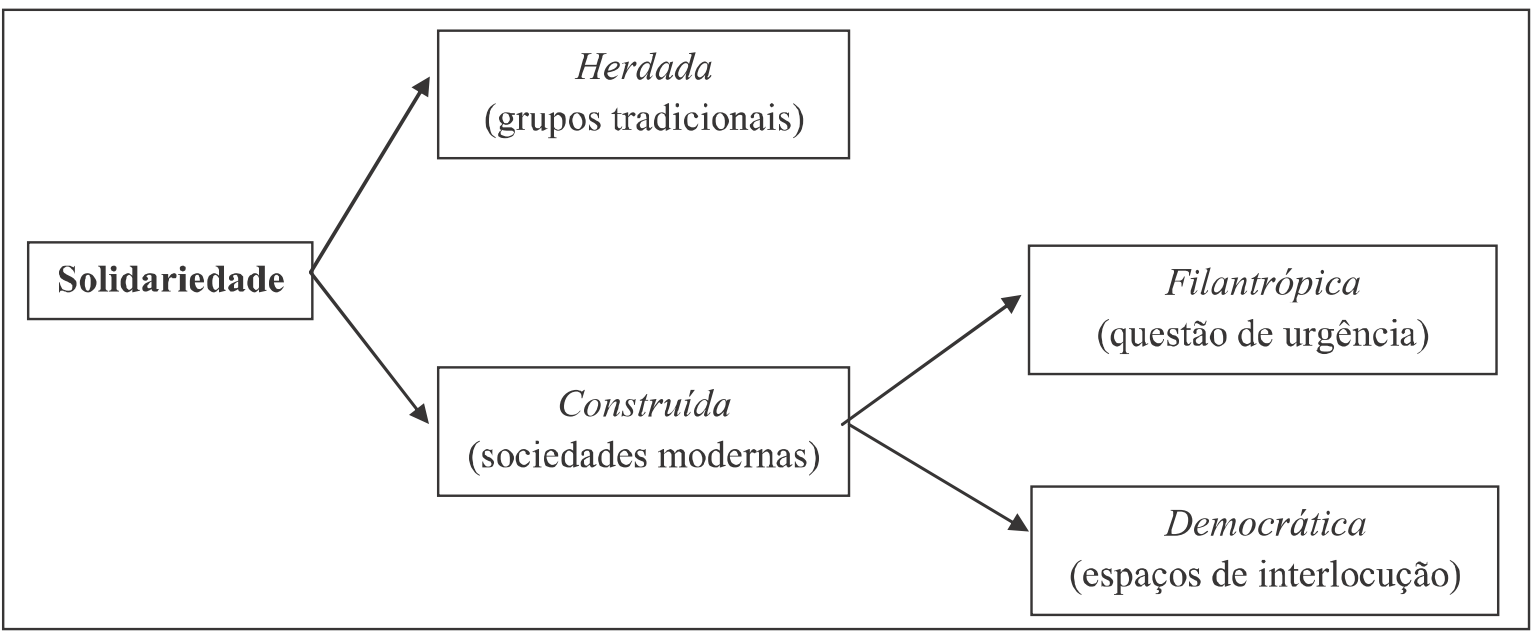

Fonte: Laville (2006, 2008). Elaboração nossa.

No que tange em específico à solidariedade filantrópica, o exame histórico revela que ela tipificou-se como uma construçáo fomentada pelo Estado. Desde a lei dos pobres (Poor Law) inglesa de 1601 percebe-se um princípio de atuaçóes paliativas do Estado a fim de amenizar contradiçóes sociais (que à época resumiam-se nas mazelas da lei dos cercamentos de terras). Anos mais tarde, tais contradiçóes acirram-se por conta da consolidaçáo do capitalismo industrial, o que certamente dá a indicaçáo da ampliaçáo das tônicas do Estado Social (ESPING-ANDERSEN, 1991). 
Incontestavelmente, esta concepção filantrópica da solidariedade era, e é ainda hoje, fortemente marcada pelas preocupações liberais. Focalizada na 'questão da urgência' e na preservação da paz social, ela tem como objeto a amenização dos problemas dos pobres e sua moralização, através das ações filantrópicas paliativas. [...] A doação [inerente à solidariedade filantrópica] é submetida apenas a regras coletivas, emitidas pelos doadores susceptíveis de estabilizar as condições deste exercício; pode assim converter-se em instrumento de poder e de dominação. (LAVILLE, 2008, p. 22-23).

No outro extremo, a solidariedade democrática caracteriza-se por compor açóes coletivas que resultam na constituiçáa de espaços públicos, onde a interlocuçáo democrática se faz sempre presente - mesmo com a presença do Estado. Nesse ínterim, fica patente que são construçóes de solidariedade 'provenientes da base'. Portanto, diz-se tratar também de uma solidariedade autêntica.

Logo, dadas essas consideraçóes conceituais, resta qualificar que a economia solidária reconstrói a tônica da organizaçáo social, alicerçando-a sob os preceitos de solidariedade com o escopo de minorar as desigualdades e demais mazelas socioeconômicas, em prol do bem viver coletivo. Portanto, tanto o viés social quanto o econômico são imbricados como um todo só, passível de uma abordagem por intermédio da solidariedade.

Pondera-se que a solidariedade nas organizaçóes de caráter econômico-solidário relega unicidade, homogeneidade e coesão aos agrupamentos, em que todos os indivíduos mutuamente auxiliam-se em prol da organizaçáo em sua totalidade. Portanto, os comportamentos fundamentados no interesse individual são superados em prol da coletividade, numa tônica em que, não raro, todos os indivíduos maximizam mutuamente seus ganhos.

\subsection{Desigualdade: ponderações acerca da 'naturalidade' inerente aos padrões classicistas de acumulação capitalista}

O sistema capitalista, em sua essência, tem no fenômeno da desigualdade uma de suas principais decorrências práticas. Imbricada na questáo da competiçáo, a definiçáo de desigualdade remonta à ideologia e autonomia inerentes ao direito de acumulaçáo do capital. Nesse sentido, o capitalismo funda-se “[...] numa relação social, entre indivíduos desigualmente posicionados face aos meios de produçáo e às condiçóes postas em relaçáo ao valor de sua capacidade de trabalho" (GAIGER, 2003, p. 188, grifo do autor). 
A própria categoria do lucro, entendido como a remuneraçáo inerente à detençáo de algum tipo de capital, induz à existência e manutenção de relaçóes desiguais entre os indivíduos. Sendo assim, a sociedade é relegada à condiçáo de palco de uma relação classicista, que se mantém "[...] através de uma colaboração ilusória, mas não menos real, das três classes básicas, os assalariados, os capitalistas e os proprietários fundiários, na qualidade de donos dos fatores responsáveis pelos custos da produçáo de mercadorias" (GIANNOTTI, 1976, p. 164).

Nesse ínterim, assiste-se ao desenrolar de um processo em que o capital, a terra e o trabalho são vistos como meras mercadorias, indispensáveis à (re) alimentaçáo do processo de acumulação e incitando, nesta dinâmica, relaçóes desiguais entre os indivíduos.

Náo obstante, muito embora a gênese da sociedade capitalista tenha a desigualdade como um de seus elementos marcantes, nota-se a existência de fatores imanentes a esse mesmo sistema capitalista que induzem a manutenção e regulação das relaçóes desiguais de acumulação de capital. Nos dizeres de Baran e Sweezy (1966, p.173-174):

Ensina-se aos jovens, desde a primeira infância, e por todos os meios concebíveis, que todos têm uma oportunidade igual, e que as desigualdades tão evidentes [no sistema capitalista] são resultado não de instituições injustas, mas de dotes pessoais superiores ou inferiores.

Sendo assim, a desigualdade é interpretada sob uma visão 'meritocrata', calcada na competiçáo entre desiguais e na bancarrota dos menos astutos, em que as forças promotoras de tais ambientes desiguais sáo "[...] naturais e decorrentes de um maior esforço e sagacidade de alguns e de falta de criatividade de outros" (CATTANI, 2003, p. 10). Observa-se, nesse imbróglio, a prevalência de uma pretensa igualdade do ponto de vista normativo - inerente à gênese do sistema capitalista - que, entretanto, náo é confirmada do ponto de vista material ou substantivo diante da prevalência de relaçóes socioeconômicas carregadas de desigualdades.

Ademais, faz-se necessário entender que a desigualdade e a competição generalizada nâo são padrôes naturais de comportamento social generalizado. Muito pelo contrário, sáo construçóes social e economicamente determinadas. 
[...] Elas [as construções socioeconômicas desiguais] resultam da forma como se organizam as atividades econômicas e que se denomina modo de produção. O capitalismo é um modo de produção cujos princípios são o direito de propriedade individual aplicado ao capital e o direito à liberdade individual. A aplicação destes princípios divide a sociedade em duas classes básicas: a classe proprietária ou possuidora do capital e a classe que (por não dispor de capital) ganha a vida mediante a venda de sua força de trabalho à outra classe. O resultado natural é a competição e desigualdade. (SINGER, 2002, p. 10, grifo do autor).

Desta feita, resta a inferência de que, nas dinâmicas de acumulação de lucro e acirramento da concentraçáo de capital, a desigualdade inerente ao sistema capitalista concorre para a reproduçáo e/ou agravamento das mazelas sociais intrínsecas à supremacia de um mercado em padrão de competiçáo (como aquelas referentes à quase inaniçâo de parcela considerável da populaçáo desprovida de capital; precarizaçáo do trabalho assalariado etc.).

Diante deste quadro, nota-se que as primeiras tentativas de superaçáo destas tônicas de desigualdade crônica datam do século XIX, nas mesmas toadas das pioneiras tentativas de promoçâo das cooperativas produtivas, calcadas nos preceitos de solidariedade.

Nesta dinâmica, a economia solidária surge como a síntese de iniciativas que visam a ultrapassar a pretensa igualdade normativa do sistema capitalista (promotora de desigualdades socioeconômicas e impulsionadora da concentraçáo de capital) em prol de igualdades substantivas, em que o bem viver dos indivíduos e o senso de solidariedade comunitária sáo alçados à condiçáo de critério organizativo dos indivíduos.

A emancipaçáo social - entendida como o processo de supremacia da sociedade e dos indivíduos em detrimento da simples acumulação de capital - é tomada como o meio sob o qual se processa esta inversáo de análise em prol da igualdade substantiva na organizaçáo socioeconômica geral.

[...] elegemos o conceito de emancipação social, no sentido de superar a ideologia de igualdade formal para a de igualdade material ou substantiva, no qual o gênero humano, enquanto um todo, pode superar o reino das necessidades e das múltiplas formas de opressão ou exploração, para um estado de liberdade efetiva, inclusive com a liberdade de determinar, coletivamente, os meios, formas e conteúdos da riqueza social produzida com a melhor combinação possível em termos de utilidade e bem estar social. (BENINI et al., 20I I, p. I80). 


\section{ii) O igualitarismo como contraponto à desigualdade}

Pensar o conceito de igualdade implica "privilegiar o todo social, a vontade coletiva, a obrigação moral supraindividual e a predominância da sociedade" em detrimento do viés meramente acumulativo e, por conseguinte, desigual inerente ao sistema capitalista (MARTINS, 2009, p. 55). Entende-se que, sob o ponto de vista de uma sociedade regida por princípios de igualdade substantiva, os fins últimos da propriedade do capital são relativizados em prol do bem viver social.

Náo se pretende, nesse ínterim, execrar a posse de capital, nos moldes dos teóricos marxistas mais ferrenhos. Objetiva-se, isto sim, negar a obtençáo e maximizaçâo do lucro como fim último da posse de capital (dinâmica esta promotora de desigualdades) em prol da utilizaçáo deste mesmo capital em favor da promoçáo do bem viver coletivo (carregado de igualdade sob o ponto de vista objetivo), o que exige, pois, a emergência de uma economia solidária.

Nesse ínterim, até mesmo o fenômeno da divisáo social do trabalho característico do modo de produçáo dominante - é ressignificado a partir da prevalência da economia solidária erigida sobre padróes igualitaristas. Longe de reforçar desigualdades a partir do estabelecimento de relaçóes hierárquicas inerentes ao modo de produçáo capitalista, a divisáo do trabalho sob a égide da economia solidária reforça a interdependência e cooperaçáo entre os indivíduos, que são tomados igualitariamente como elementos de um corpus homogêneo, que é a sociedade.

Sendo assim, na divisão social do trabalho sob padróes da economia solidária,

[...] cada um desempenha uma atividade especializada da qual resulta um produto que só tem utilidade quando complementado pelos produtos de outras atividades. O médico só consegue curar o paciente com a ajuda dos remédios fornecidos pelas farmácias e pelos serviços prestados por hospitais, ambulâncias, laboratórios etc. O mesmo vale para quem nos abriga, alimenta, veste, transporta, e assim por diante. (SINGER, 2002, p. 9).

Portanto, com base nos princípios imanentes à economia solidária, cada tipo de trabalho é tomado como detentor de parcela de importância na organizaçáo socioeconômica, de tal modo que tais parcelas sáo uniformes e interdependentes. Logo, o que importa para a economia solidária é a sociedade e o 
bem viver coletivos, ajustados igualitariamente e, assim, contrapostos à mera competição dos mercados.

Entende-se, ademais, que o senso de 'sentir-se igual aos demais' nas organizaçóes de caráter econômico-solidário relega maior autoestima aos indivíduos, o que - do ponto de vista meramente organizacional - pode maximizar a eficiência e eficácia do agrupamento.

\subsection{Heterogestão: em tela, a perspectiva administrativa dos grupos}

Prosseguindo com o propósito de apresentaçáo da gênese da economia solidária, nota-se que um dos elementos mais determinantes da antítese entre os sistemas capitalista e solidário reside na essência sob a qual as empresas são administradas.

Nas empresas capitalistas, em específico, predomina o fenômeno da heterogestáo, que reforça o caráter hierárquico e desigual inerente à posse do capital. Nos moldes expostos por Benini (2008, p. 69), nota-se que o sistema de heterogestão capitalista,

[...] tem como característica marcante a divisão do trabalho no máximo de pequenas tarefas possiveis: divisão entre os que coordenam/dirigem dos que executam/trabalham e, consequentemente, a fragmentação do conhecimento dos processos de produção e a fragmentação das relações de trabalho entre as pessoas; cada trabalhador relaciona-se mecanicamente com os demais colegas dentro da estreita necessidade de execução de suas tarefas.

Complementando o argumento proposto, Singer (2002, p. 16-17) salienta que a heterogestão tipifica-se como sendo "[...] a administração hierárquica, formada por níveis sucessivos de autoridade, entre os quais as informaçóes e consultas fluem de baixo para cima e as ordens e instruçóes de cima para baixo". Nesse ínterim, fica evidente a assimetria de informaçóes imanente à heterogestáo capitalista, de tal modo que os detentores de mais informaçóes possuem 'vantagens competitivas'.

Diante disso, nota-se que a heterogestão apresenta um caráter dual do ponto de vista objetivo, para as empresas capitalistas: ela tanto pode concorrer para a canalizaçáo de energias e reduçáo de custos em prol da maximizaçáo de lucros; assim como pode acirrar a luta entre trabalhadores pela obtençáo (ou restriçáo) de informaçóes estratégias que lhes releguem vantagens competitivas, prejudicando, pois, o bom andamento das organizaçóes. Sendo assim, 
Singer (2002, p. 17) comenta que as empresas capitalistas sempre procuraram trabalhar sob um regime de 'sintonia fina', numa tônica que prima por "[...] coibir o que seria excesso de competição, sem coibir a competiçáo sadia”. Entretanto, percebe-se que tal ponto ideal de equilíbrio dificilmente é alcançado - ora a heterogestáo concorre para a maximizaçáo dos lucros e reduçáo dos custos, ora acirra a desorganização ao nível interno das organizaçôes.

Ademais, não há como se falar em heterogestão capitalista sem se remeter ao fenômeno de alienaçáo da força de trabalho. Entendido como uma funcionalidade do capital, em que o trabalhador é acima de tudo dominado pelas condiçóes de trabalho sob as quais náo tem poder, a alienaçáo resulta na máxima da separação do trabalhador em relação aos meios de produção, bem como em relação às mercadorias resultantes de seu trabalho (NOVAES, 2010; MARX, 2004). ${ }^{8}$

Com base nesta dinâmica, "[...] a alienação é composta de aspectos políticos (e náo atributos subjetivos individualizados), sendo que as relaçóes de propriedade sáo conditio sine quo non para que o aspecto econômico possa operar" (BENINI; BENINI, 2010, p. 612). Nesse ínterim, percebe-se que o sistema capitalista funda-se na alienaçáo do trabalho, de tal modo que a heterogestão (por tipificar-se pelos aspectos funcionais de acumulaçáo de lucros) resume-se em um elemento catalisador das relaçóes de alienaçáo do trabalho e, consequentemente, das relaçóes de acumulaçáo de capital via reforço das tônicas capitalistas excludentes.

Imbricado na questão da alienação, o fenômeno de precarização do trabalho resume-se em outra decorrência do princípio de heterogestáo capitalista. Tipificado como a ocupação de trabalhos subalternos e alienantes, sobretudo por aqueles que náo detêm o mínimo de informaçáo na dinâmica de ampliaçáo dos lucros, a precarizaçáo do trabalho é calcada na heterogestáo à medida que a hierarquizaçáo ao nível das organizaçóes amplia o fosso existente entre aqueles que ocupam as funçóes diretivas (dentro da lógica do capital) em

8 Marx, nos seus Manuscritos Econômico-Filosóficos, tratará da alienação sob quatro dimensões básicas: a alienação do homem em relação à natureza; a alienação do homem em comparação a sua própria atividade produtiva; a alienação do homem em relação aos outros membros da sociedade; e, por fim, a alienação do homem como 'membro de sua espécie'. Dado que o objetivo do presente trabalho não se resume à análise do fenômeno da alienação, optou-se pela adoção do conceito o mais sintético possivel (MARX, 2004). 
detrimento daqueles que exercem as funçôes na dinâmica do processo produtivo, quase sempre a baixos salários e condiçôes insalubres.

Com base nesta tônica, fatalmente surgem os movimentos de contestação dos princípios imanentes à heterogestáo capitalista promotora de alienaçáo e precarização da força de trabalho. Nesse ínterim, surge, pois, o princípio da autogestáo - evocado pelo movimento da economia solidária.

iii) A autogestão como resposta à heterogestão

O princípio da autogestáo característico às empresas econômico-solidárias tipifica-se como um arranjo em que as instâncias decisórias ao nível das organizaçóes são tomadas democraticamente pelos próprios trabalhadores. Nesse ínterim, caem por terra os elementos hierarquizados característicos da heterogestáo em prol das horizontalidades inerentes à autogestão solidária. Ademais, o trabalho é tomado sob uma perspectiva integral - em que os trabalhadores sáo os possuidores dos meios de produçâo e das mercadorias resultantes de seus respectivos trabalhos - numa clarividência de negaçáo dos preceitos alienantes do sistema capitalista hierárquico e excludente.

A autogestáo, em síntese, particulariza-se pelo náo antagonismo entre os membros de uma determinada organizaçáo solidária. No entender de Benini (2008, p. 71) a autogestáo caracteriza-se pela "[...] recuperaçâo dos laços de solidariedade ainda dentro dos processos produtivos, por meio da transparência da gestão, divisâo de poder e dos ganhos e enriquecimento de tarefas por meio de uma participaçáo ativa dos sócio trabalhadores".

Singer (2002, p. 21) pondera que "a autogestáo tem como mérito principal náo a eficiência econômica (necessária em si), mas o desenvolvimento humano que proporciona aos participantes". Entende-se que a própria sensação de 'sentir-se dono' das organizaçóes solidárias calcadas nas instâncias democráticas de decisão, ou a própria percepção de 'ser soberano' intrínseca à detenção, pelo trabalhador, dos meios e dos fins do produto de seu trabalho constituem elementos que, por si só, concorrem para a promoção do bem viver dos indivíduos (MELO NETO, 2005).

Gaiger (2003, p. 193), ao correlacionar as questóes referentes à autogestão com os preceitos imanentes à cooperação e solidariedade, pondera que: 
A autogestão e a cooperação são acompanhadas por uma reconciliação entre o trabalhador e as forças produtivas que ele detém e utiliza. Não sendo mais um elemento descartável e não estando mais separado do produto do seu trabalho, agora sob seu domínio, o trabaIhador recupera as condições necessárias, mesmo se insuficientes, para uma experiência integral de vida laboral e ascende a um novo patamar de satisfação, de atendimento a aspirações não apenas materiais ou monetárias.

A economia solidária, que tem como lógica a promoção do bem viver coletivo, nâo poderia se furtar aos debates referentes à autogestão. Muito pelo contrário, ela toma para si a autogestáo como um de seus elementos determinantes, à medida que permite uma interpretaçáo da sociedade sob uma perspectiva horizontal, sem distinção de classes e/ou relaçóes hierárquicas de produçáo.

Mais uma vez, conforme expóe Singer (2002, p. 21), parte-se do pressuposto de que ao "[...] participar das discussóes e decisóes do coletivo, ao qual se está associado, educa e conscientiza, tornando a pessoa mais realizada, autoconfiante e segura”, a economia solidária clama para si a funçáo de promover o bem-estar dos indivíduos de forma democrática e autônoma, naturalmente por intermédio dos princípios da autogestáo, solidariedade e igualdade.

\section{Paradigma da abundância versus paradigma da escassez: em tela a construção dos 'fundamentos econômicos' da economia solidária}

Dados a síntese dos aspectos histórico-sociológicos, bem como o delineamento dos fundamentos gerais da economia solidária, parte-se agora à qualificaçáo do assunto sob a perspectiva da economia política ortodoxa (muito embora em várias partes do texto já se tenha feito mençáo, mesmo que involuntariamente, a esses aspectos).

Nesse sentido, analisar os fundamentos econômicos da economia solidária, muito embora talvez se encerre em tautologia numa exegese do termo, resume-se na investigaçâo dos preceitos da economia política ortodoxa (como os mecanismos de formaçáo de preços e controle de oferta/demanda com base no paradigma utilitarista da escassez) e, com base nisso, na apresentaçáo dos fundamentos da economia solidária como contrapontos a esses preceitos basilares.

O sistema capitalista, por erigir-se na lógica de maximização dos lucros e acumulaçáo de capital, parte do pressuposto de que os bens/serviços 
resultantes dos processos produtivos, quanto mais escassos, maiores serão os seus níveis de preços e, por conseguinte, maiores as margens de lucros (concebida como a remuneraçáo pela posse do capital). Parte-se, portanto, do paradigma da escassez dos produtos diante das necessidades ilimitadas dos indivíduos, de tal modo que a ciência econômica capitalista, nesse ínterim, seria a responsável por pensar e gerir esse conflito (escassez versus necessidades ilimitadas).

"A famosa 'lei' da oferta e da procura supóe que o preço de um determinado bem ou serviço, sob essa lógica de mercado, é tanto maior quanto mais escasso ele for em relaçáo à demanda que atende" (MANCE, 2002, p. 101). Sendo assim, sob a égide do paradigma da escassez, um bem abundante e livre (como o ar ou a luz solar, por exemplo) não é passível de determinação de preços.

Digo que as coisas existem à nossa disposição apenas em quantidade limitada desde que elas não existam em quantidade tal que cada um possa encontrá-las ao alcance e à vontade para satisfazer inteiramente a necessidade que tem delas. Há no mundo certo número de utilidades que, desde que não faltem completamente, existem à nossa disposição em quantidade ilimitada. Assim, o ar atmosférico, a luz e o calor do sol, quando o sol brilha, a água às margens dos lagos, dos rios e dos riachos são encontrados em tal quantidade que não podem fazer falta a ninguém, cada um podendo mesmo deles tomar tanto quanto queira. (WALRAS, 1983, p. 20).

Nota-se que, com base no paradigma da escassez, quanto mais evidente for a abundância de bens e serviços em relaçáo à demanda numa determinada economia, menor será a riqueza social ${ }^{9}$ inerente a essa economia. Sob o ponto de vista normativo, tal dinâmica é um tanto quanto evidente (é a máxima da 'lei da oferta e da procura' e seus reflexos). Porém, do ponto de vista substantivo, como explicar que produtos abundantes, porém essenciais (como o ar ou a luz do sol, por exemplo) não apresentam preços e/ou possuem preços minorados em relaçáo a produtos náo essenciais?

A resposta reside, pois, na questão do valor e em seus aspectos determinantes. Produtos essenciais apresentam elevado valor de uso, entendido como aquilo que é indispensável à sobrevivência humana, não raro sendo apropriado

9 O termo riqueza social é entendido como "[...] o conjunto de coisas materiais ou imateriais [...] que são raras, isto é, que nos são, por um lado, úteis e que, por outro, existem à nossa disposição apenas em quantidade limitada" (WALRAS, 1983, p. 19). 
sem a utilização de trabalho (como a 'apropriação' do ar ou da luz solar, por exemplo, que não demanda trabalho em sua forma socialmente determinada). Porém, os produtos só apresentarão um preço e, assim sendo, só contribuiráo com a riqueza social a partir do momento em que possuírem um determinado valor de troca, interpretado como a relação inerente à demanda em relação à escassez de oferta dos produtos. ${ }^{10}$

Náo obstante, deve-se deixar claro que a relaçáo que perpassa toda a dinâmica do valor é a utilidade do bem, dado que "[...] nenhuma coisa pode ser valor se não é objeto útil” (MARX, 1975, p. 48). Ademais, todos os produtos apresentam, numa abstraçáo mais primitiva, valor de uso, de tal modo que o aspecto que determina seus respectivos valores de troca reside na dinâmica de apropriação, permuta e multiplicação dos bens, que encerra, pois, a própria dinâmica dos mercados capitalistas.

Mais uma vez retornando a Walras (1983), nota-se que a apropriação refere-se ao recolhimento e à assimilação de bens úteis e limitados, seja para consumo próprio ou para fins de troca, relegando aos seus respectivos detentores poder coercitivo. Dada uma suposta escassez do produto apropriado, denota-se a faculdade de permutá-lo a um determinado preço, calcado na relaçáo entre a oferta e demanda deste mesmo produto nos mercados capitalistas. Incluindo, pois, na análise o pressuposto das necessidades ilimitadas dos indivíduos (demanda ilimitada), fica subjacente o preceito de multiplicação dos produtos apropriáveis e permutáveis, lançando-se mão dos aparatos industriais para tanto, ampliando, pois, a riqueza social (e, por conseguinte, a riqueza dos detentores dos aparatos de multiplicaçáo, ou seja, dos detentores do capital).

Nota-se que o grande catalisador desta dinâmica (apropriação-permuta-multiplicação) reside no preceito de ampliaçáo da riqueza social, interpretada como a disponibilidade de bens úteis nos mercados face à demanda ilimitada. Nesse ínterim, o capital é alçado à condiçáo de fator promotor do bem-estar

10 Com relação à questão do valor, algumas ponderações conceituais devem ser feitas, dado que é comum ver textos em que valor e preço de uma determinada mercadoria são tomados como conceitos equivalentes. Mance (2002, p. I 15) ao interpretar Marx considera que "[...] não se deve confundir o valor de troca de um bem - que pode ser calculado considerando-se a quantidade socialmente necessária de trabalho requerida em sua produção - com o preço pelo qual é efetivamente trocado no mercado, que oscila pelas alterações de oferta e demanda". 
social ao proporcionar a ampliação da riqueza social face à multiplicação dos bens úteis.

Porém, neste ponto, é curioso rememorar um questionamento exposto por Mance (2002, p. 108), que pondera: “o que ocorre se alguém não tiver nada para trocar que lhe permita aceder a algum bem do qual necessita, mas do qual está privado pela 'propriedade legítima' de outro?” Eis que surge o aspecto negativo inerente ao paradigma da escassez intrínseco aos mercados capitalistas, que considera que "[...] se alguém náo dispóe de coisas úteis e raras para trocar, deve privar-se daquilo de que necessita, não se colocando em questão a relevância daquela necessidade” (MANCE, 2002, p. 109).

Portanto, se os indivíduos náo dispóem de capital (seja sob a forma de dinheiro, ou até sob a forma de força de trabalho - sua própria força de trabalho), ou se o capital de que dispóem não é demandado por aqueles que se apropriaram dos bens úteis e escassos, nota-se que tais bens sáo negados a esses tipos de indivíduos.

Portanto, ficam evidentes as contradiçóes e desigualdades inerentes aos mercados capitalistas sob o paradigma da escassez. Como contraponto a essas questóes, a economia solidária, sob uma lógica distinta - a lógica do bem viver, furta-se ao paradigma da escassez e apresenta, pois, outra dinâmica calcada no equilíbrio, em que o atendimento aos anseios sociais náo fique dependente da propriedade de produtos escassos que cada um tenha para trocar no mercado.

Sendo assim, a economia solidária funda-se no que se convencionou denominar de paradigma da abundância, no qual o preço náo se regula pela escassez nem pelo tempo de trabalho, mas sim por aspectos definidos democraticamente pelos indivíduos, em que o preço reflete elementos necessários à subsistência e ao bem viver da coletividade, em sua totalidade. Trata-se, pois, de almejar a estipulaçáo de um preço justo, o que implica apreciar outros elementos além daqueles considerados pela economia ortodoxa fundamentada no paradigma da escassez.

No entender de Mance (2002, p. 116) a economia solidária sob o paradigma da abundância resume-se em uma dinâmica que trata de:

[...] ampliar a produção de valores de uso a tal monta que se garanta o bem-viver ao conjunto das sociedades [...]; não se trata de acumular valores de troca que somente poderiam ser valores, sob a lógica do mercado, caso fossem escassos. 
Mance (1999) considera ainda que a economia solidária calcada no paradigma da escassez desenrola-se nas chamadas redes de colaboração solidária, que sáo os espaços onde se estabelecem as relaçóes entre os grupos que produzem e comercializam calcados nos preceitos da economia solidária. Numa analogia à economia capitalista, as redes de colaboraçáo solidárias seriam os 'mercados' imanentes à economia solidária.

A partir da evidência do paradigma da abundância nas redes solidárias, quanto mais se partilha a riqueza - a partir dos preceitos de preço justo e, em assim sendo, com base na remuneraçáo justa do trabalho ${ }^{11}$ - tanto mais se incrementa, sob parâmetros sustentáveis, o consumo no interior das próprias redes, fomentando, pois, a sua (re)alimentaçáo.

Nesse ínterim, o próprio Mance (1999) considera que a dinâmica de (re) alimentaçấo das redes, bem como os desvios dos fluxos de renda dos mercados para as redes solidárias, proporcionaráo o incremento destas mesmas redes a taxas crescentes, sob um efeito multiplicador.

Náo obstante, neste ponto, uma ponderaçáo surge: quais os fatores que impulsionaráo o consumo e os desvios de fluxos de renda em direçáo das redes solidárias? Nesse sentido, preceitua-se que a própria ideia de preço justo e remuneraçáo justa do trabalho sáo aspectos positivos das redes, sobretudo do ponto de vista da produçáo (oferta). Náo obstante, outros fatores de cunho eminentemente microeconômico atinentes à demanda (como as economias de escopo referente à proximidade dos ofertantes em relação à demanda; a rápida difusáo de conhecimento e adequaçóes sociotecnológicas intrínsecas a esta mesma vantagem de localizaçáo; a personalizaçáo inerente aos produtos provenientes da economia solidária etc.) sáo aspectos positivos das redes solidárias, concorrendo, pois, para os desvios dos fluxos de renda dos mercados em direçáo às redes de colaboraçáo solidárias (PINDYCK; RUBINFIELD, 2006; MANCE, 1999).

Dadas essas consideraçóes cabe, por fim, um comentário acerca da abundância, inerente ao paradigma da abundância na economia solidária. Antes de tudo, deve-se citar que o conceito de abundância náo se confunde com o

II Entende-se que a evidência de um preço justo incorre em uma remuneração igualmente justa do trabalho. Sendo assim, não há expropriação do trabalho alheio (ou extração da mais-valia, nos termos marxistas), negando, pois, as desigualdades intrinsecas ao paradigma da escassez nos mercados sob a tutela do capital. 
conceito de excesso. Enquanto o primeiro termo refere-se à promoçáo do que é eminentemente necessário (incluindo, aí, uma margem produtiva de segurança que permita aos indivíduos um mínimo de planejamento), o segundo termo induz à ideia do que seria exagerado e desmedido, logo: com uma margem que é desnecessária, além da margem de segurança.

Mais uma vez, recorrendo a Mance (2002, p. 125), nota-se que:

A abundância, pois, não se confunde com o excesso, com o demasiado, em relação ao que assegure o bem-viver. Seus parâmetros flexíveis oscilam sempre em uma franja que está além do que seja necessário - gerando tranquilidade e despreocupação frente a algum imprevisto possível e/ou provável - e aquém do que seja excessivo, evitando-se gerar perdas ou dejetos que prejudiquem o ecossistema, que subtraiam injustamente mediações requeridas à liberdade pública, ou que inviabilizem o bem-viver da própria pessoa.

Portanto, ficam assim explicitadas as lógicas econômicas imanentes à economia solidária. Desde já, notam-se sugestóes de aspectos contemporâneos sobre os quais a economia solidária, como campo analítico, constantemente tem seu discurso (re)transformado, dentre os quais pontua-se: as questóes ambientais; as relaçóes de gênero; as imbricaçóes da economia solidária em atividades marcadamente capitalistas; a perspectiva da educaçáo para a economia solidária etc.

No tópico seguinte, são tangenciadas algumas questôes a partir da análise do movimento de economia solidária no contexto da perspectiva instrumental das políticas públicas, específicas do caso deste movimento no Brasil.

\section{I A economia solidária como política pública no Brasil}

Pensar os aspectos contemporâneos, bem como levantar hipóteses acerca do futuro da economia solidária, resume-se num expediente que necessariamente perpassa a tese de que tal temática insere-se como política pública, notadamente no que se refere à atuaçáo do Estado no combate às desigualdades socioeconômicas. Nesta perspectiva, Singer (2002, p. 112) pontua que “[...] o avanço [contemporâneo] da economia solidária náo prescinde inteiramente do apoio do Estado e do fundo público, sobretudo para o resgate de comunidades miseráveis, destituídas do mínimo de recursos que permita encetar algum processo de auto emancipaçáo". 
As primeiras propostas de fomento à economia solidária, no Brasil, datam da década de 1980, período em que muitas entidades, marcadamente ligadas aos movimentos sociais e/ou à questáo do desemprego (já marcante na época), começaram a pensar em novas alternativas que fizessem frente ao contexto de crise socioeconômica reinante no período em tela.

Dentre as primeiras Entidades de Apoio e Fomento (EAF) à economia solidária, nota-se que uma das pioneiras foi a Cáritas, “[...] uma entidade ligada à Conferência Nacional dos Bispos do Brasil (CNBB), que desde os anos 1980 já financiava milhares de pequenos projetos denominados PACs Projetos Alternativos Comunitários” (FRANÇA FILHO, 2006, p. 64).

Com o passar dos anos, nos idos de 1990, os movimentos operários e sindicais, capitaneados pela Central Única dos Trabalhadores (CUT) começam a inserir-se nos princípios de discussóes acerca de uma economia solidária. Nesta proposta, em 1999, origina-se no contexto da CU'T a Agência de Desenvolvimento Solidário (ADS), gestada em parceria com a Fundaçáo Unitrabalho e o Departamento Intersindical de Estatísticas e Estudos Socioeconômicos (Dieese).

Náo obstante, ainda na década de 1990, surgem, no seio dos movimentos universitários, as chamadas Incubadoras Tecnológicas de Cooperativas Populares (ITCPs), que representam entidades que:

[...] atendem grupos comunitários que desejam trabalhar e produzir em conjunto, dando-lhes formação em cooperativismo e economia solidária e apoio técnico, logístico e jurídico para que possam viabilizar seus empreendimentos autogestionários. (SINGER, 2002, p. 123).

Finalmente, em junho de 2003 (como consequência dos debates e das indicaçôes decorrentes do Fórum Social Mundial) cria-se o Fórum Brasileiro de Economia Solidária (FBES) como instância organizativa das várias EAF ligadas à economia solidária, bem como se origina a Secretaria Nacional de Economia Solidária (SENAES), no âmbito do Ministério do Trabalho e Emprego (MTE), que, notadamente, representou o marco da institucionalizaçáo do movimento de economia solidária na perspectiva das políticas públicas.

Organizado no seio da SENAES como estratégia para a reuniáo de informaçóes de Empreendimentos Econômicos Solidários (EES) e de EAF, o Sistema Nacional de Informaçôes em Economia Solidária (SIES) perfaz uma 
plataforma que permite o acompanhamento das especificidades da economia solidária no Brasil, subsidiando, pois, o estabelecimento de políticas públicas por intermédio desta temática.

No ano de 2007, segundo informaçóes do SIES, havia no Brasil (até o ano em tela) 21.859 EES, organizados da seguinte forma: associaçóes (52\% do total de empreendimentos); cooperativas (10\%); grupos informais (36\%); além de outras formas de organizaçáo $(2 \%)$.

\section{Considerações finais}

A economia solidária - como quadro teórico-analítico das ciências sociais - erigiu-se como uma reação aos desígnios excludentes do modo de produção capitalista. Desta feita, a construçáo dos fundamentos da economia solidária se dá a partir de uma perspectiva de negação/adaptação dos próprios fundamentos do sistema capitalista. Logo, entende-se que a economia solidária surge como uma forma de humanização do sistema capitalista, contrapondo os aspectos essencialmente utilitaristas deste sistema.

Não obstante, a despeito de todo o aspecto de fundo revolucionário e adaptativo inerente à economia solidária - aspecto este mais detidamente trabalhado no correr deste artigo - deve-se ponderar que a economia solidária, contemporaneamente, mostra-se como mecanismo de política pública, não raro concebida de forma funcional às dinâmicas do sistema capitalista.

Há uma imbricação contemporânea das Entidades de Apoio e Fomento à economia solidária numa verdadeira rede de apoio ao empreendedorismo solidário, o que perpassa pelos movimentos sociais, pelo poder público e até pela universidade, através de Rede de Incubadoras Tecnológicas de Cooperativas Populares.

Portanto, urgem novas pesquisas acerca das especificidades da economia solidária como política pública, sobretudo no que tange aos aspectos relativos à conciliaçáo de seus fundamentos basilares à própria perspectiva funcional intrínseca às políticas públicas, de forma geral.

Ademais, devem-se privilegiar investigaçóes acerca das potencialidades da economia solidária como método de promoçáa de bem-estar, geraçáo de renda, manutençáo das especificidades socioculturais dos indivíduos e catalisador das dinâmicas de desenvolvimento dos territórios. 


\section{Referências}

ARROYO, J. C. T; SCHUCH, F. C. Economia popular e solidária: a alavanca para um desenvolvimento sustentável. São Paulo: Ed. Fundação Perseu Abramo, 2006.

BARAN, P.; SWEEZY, P. Capitalismo monopolista. Rio de Janeiro: Zahar, 1966.

BARBOSA, R. N. C. A economia solidária como política pública: uma tendência de geração de renda e ressignificaçáo do trabalho no Brasil. São Paulo: Cortez, 2007.

BENINI, E. A.; BENINI, E. G. As contradiçóes do processo de autogestáo no capitalismo: funcionalidade, resistência e emancipação pela economia solidária. Revista O\&S, Salvador, n. 55, p. 605-619, out./dez. 2010.

BENINI, E. A.; BENINI, E. G.; IPOLITO, J. C. A educaçáo no contexto da economia solidária: problemáticas para uma práxis emancipatória. In: BATISTA, E. L.; NOVAES, H. (Org.). Trabalho, educaçáo e reproduçáo social: as contradiçóes do capital no século XXI. Sáo Paulo: Canal 6 Editora, 2011.

BENINI, E. G. Economia solidária em questáo: estudo sobre as possibilidades e limites de inserçáo e emancipação social no capitalismo. 2008. Dissertação (Mestrado em Economia) - Universidade Federal de Mato Grosso do Sul, Campo Grande, 2008.

BIÉLER, A. O pensamento econômico e social de Calvino. Sáo Paulo: Casa Editora Presbiteriana, 1990.

BLOCK, F.; POLANYI, K. Karl Polanyi and the writing of "The great transformation". Theory and Society Review, v. 32, n. 3, p. 275-306, June 2003.

CARCANHOLO, R. O valor, a riqueza e a teoria de Smith. Revista Análise Econômica, Porto Alegre, ano 9, n. 15, p.183-205, mar. 1991.

CATTANI, A. D. A outra economia: os conceitos essenciais. In: CATTANI, A. D. (Org.). A outra economia acontece. Porto Alegre: Veraz, 2003.

CORIOLANO, L. N. M. T. O turismo comunitário e a economia solidária no Ceará. In: SEMINÁRIO INTERNACIONAL DE TURISMO SUSTENTÁVEL. 2., 2008, Fortaleza. Anais... Fortaleza, CE: UECE, 2008. 18 p.

CRESWELL, J. W. Projeto de pesquisa: métodos qualitativo, quantitativo e misto. 3. ed. Porto Alegre: Artmed, 2010.

ESPING-ANDERSEN, G. As três economias políticas do welfare state. Revista Lua Nova, São Paulo, n. 24, p. 85-116, 1991. 
FRANÇA FILHO, G. C. Terceiro setor, economia social, economia solidária e economia popular: traçando fronteiras conceituais. Bahia Análise \& Dados, Salvador, v. 12, n. 1, p. 9-19, 2002. A economia popular e solidária no Brasil. In: FRANÇA FILHO, G. C. et al. (Org.). Açáo pública e economia solidária: uma perspectiva internacional. Porto Alegre: Ed. da UFRGS, 2006. FRANÇA FILHO, G. C. et al. (Org.). Açáo pública e economia solidária: uma perspectiva internacional. Porto Alegre: Ed. da UFRGS, 2006.

GAIGER, L. I. G. A economia solidária diante do modo de produção capitalista. Caderno CRH, Salvador, n. 39, p.181-211, jul./dez. 2003.

GIANNOTTI, J. A. Notas sobre a categoria "modo de produção" para uso e abuso dos sociólogos. Estudos CEBRAP, Sáo Paulo, n. 17, p. 161-168, 1976.

GOMES, A. M. A. Origens e imagens do protestantismo brasileiro no século XIX numa perspectiva calvinista e weberiana. Revista Ciências da Religião - História e Sociedade, Sáo Paulo, v. 1, n. 1, p. 68-113, 2003.

GUÉSLIN, A. L’invention de l'économie sociale. Paris: Econômica, 1998, 198 f.

GUILLERM, A.; BOURDET, Y. Autogestáo: mudança radical. Rio de Janeiro: Zahar, 1976.

LAVILLE, J. L. Ação pública e economia solidária: um quadro de análise. In: FRANÇA FILHO, G. C. et al. (Org.). Açáo pública e economia solidária: uma perspectiva internacional. Porto Alegre: Ed. da UFRGS, 2006.

Do século 19 ao século 21: permanência e transformaçóes da solidariedade em economia. Revista Katálysis, Florianópolis, v. 11, n. 1, p. 20-42, jan./jun. 2008. Solidariedade. In: CATTANI, J. L.; LAVILLE, J. L.; HESPANHA, P. (Coord.). Dicionário internacional da outra economia. Sáo Paulo: Almedina, 2009.

LECHAT, N. M. P. Economia social, economia solidária, terceiro setor: do que se trata? Civitas Revista de Ciências Sociais, Porto Alegre, ano 2, n. 1, p. 123-140, 2002.

MANCE, E. A. A revoluçáo das redes: a colaboraçáo solidária como uma alternativa pós-capitalista à globalizaçáo atual. Petrópolis: Vozes, 1999.

MANCE, E. A. Redes de colaboraçáo solidária: aspetos econômico-filosóficos: complexidade e libertação. Petrópolis: Vozes, 2002.

MARTINS, P. H. Cidadania. In: CATTANI, J. L.; LAVILLE, J. L.; HESPANHA, P. (Coord.). Dicionário internacional da outra economia. São Paulo: Almedina, 2009.

MARX, K. Manuscritos econômico-filosóficos. São Paulo: Boitempo, 2004. 
O capital: livro I. Rio de Janeiro: Civilização Brasileira, 1975.

MÉSZÁROS, I. A educação para além do capital. Sáo Paulo: Boitempo, 2005.

MOTTA, F. C. P. Alguns precursores do participacionismo. In: VENOSA, R. Participaçáo e participaçóes: ensaios sobre autogestáo. Sáo Paulo: Babel Cultural, 1987.

NASCIMENTO, A. F. Economia popular solidária: alternativa de geração de trabalho e renda e desafio aos profissionais do Serviço Social. Revista Textos \& Contextos, Porto Alegre, v. 6, n. 2, p. 264-281, 2007.

MELO NETO, J. F. Autogestão. In: CANDEIAS, C. N. B.; MACDONALD, J. B.; MELO NETO, J. F. (Org.). Economia solidária e autogestáo: ponderaçóes teóricas e achados empíricos. Maceió: EDUFAL, 2005.

NOVAES, H. T. A relação universidade-movimentos sociais na América Latina: habitação popular, agroecologia e fábricas recuperadas. 2010. Tese (Doutorado em Política Científica e Tecnológica) - Universidade Estadual de Campinas, Campinas, 2010.

NUNES, D. Incubaçáo de empreendimentos de economia solidária: uma aplicaçáo da pedagogia da participaçáo. Sáo Paulo: Annablume, 2009.

Paulo: Canal 6 Editora, 2011.

PINDYCK, R. S.; RUBINFIELD, D. L. Microeconomia. São Paulo: Prentice Hall, 2006.

PINTO, J. R. L. Economia solidária: de volta à arte da associaçáo. Porto Alegre: Ed. da UFRGS, 2006.

POLANYI, K. A grande transformaçáo: as origens da nossa época. 2. ed. Rio de Janeiro: Elsevier, 2000.

SINGER, P. As grandes questóes do trabalho no Brasil e a economia solidária. Revista Proposta, Rio de Janeiro, n. 97, p. 12-16, jul./ago. 2003.

Globalização e desemprego: diagnóstico e alternativas. 7. ed. São Paulo: Contexto, 2006. Introduçáo à economia solidária. São Paulo: Ed. Fundação Perseu Abramo, 2002.

SMITH, A. A riqueza das naçóes. São Paulo: Abril Cultural, 1983. v. 2.

WALRAS, L. Compendio dos elementos de economia política pura. Sáo Paulo: Abril Cultural, 1983.

Data de recebimento: 25.10 .2012

Data de aprovação: 28.08.2013 


\section{The construction of conceptual framework of Solidarity}

\section{Abstract}

This paper aims to shed light on the basic fundamentals of the solidarity economy, placing it in relation to the historical, sociological and even economic factors that are relevant to understand this theme. It is understood that the solidarity economy - while the referential framework of the social sciences - was developed with a view to adapt/deny of the excluding and cumulative purposes of the capitalism mode of production, in an attempt to humanize this system. Thus, all the analytical framework of the solidarity economy was built on this work from this perspective of adapt/deny of the basic foundations of the capitalist system. That work is, therefore, a result of a research article essentially qualitative, descriptive and exploratory character - especially on account of the contemporaneity in this theme. It was concluded by the gathering of information, that need most research on the contemporary practices of solidarity economy, placing them within public policies, as well as in the development of the social economy as an organized movement.

Keywords: Solidarity Economy, Capitalism, Sociology 